Table 1. TITRES OF VIRUS AND INTERFERON PRODUCED AFTER INOCULATION of Surviving Calf Tongee EPITHelial Cultures $\begin{array}{llll}\text { Virus strain Day } 1 & \text { Day } 2 & \text { Day } 3\end{array}$

\begin{tabular}{|c|c|c|c|c|c|c|}
\hline & Virus strain & & Day 1 & Day 2 & Day 3 & Day 4 \\
\hline Exp. 1 & $\begin{array}{l}O V E N \\
O A T T V I\end{array}$ & $\begin{array}{l}\mathrm{V}^{*} \\
\mathrm{I} \dagger \\
\mathrm{V} \\
\mathrm{I}\end{array}$ & $\begin{array}{l}6 \cdot 2 \\
0 \\
\mathbf{5} \cdot \mathbf{7} \\
\mathbf{1} \cdot \mathbf{2}\end{array}$ & $\begin{array}{l}6 \cdot 2 \\
0 \cdot 2 \\
5 \cdot 4 \\
4 \cdot 5\end{array}$ & $\begin{array}{l}5 \cdot 5 \\
1 \cdot 2 \\
5 \cdot 1 \\
2 \cdot 5\end{array}$ & $\begin{array}{l}4 \cdot 9 \\
0 \\
5 \cdot 0 \\
2 \cdot 0\end{array}$ \\
\hline Exp. 2 & $\begin{array}{l}O V E N \\
O A T T V I \\
O A T T X I I\end{array}$ & $\begin{array}{l}\text { V } \\
\text { I } \\
\text { V } \\
\text { I } \\
\text { V } \\
\text { I }\end{array}$ & $\begin{array}{l}6 \cdot 25 \\
0 \\
4 \cdot 5 \\
0 \\
4 \cdot 6 \\
0\end{array}$ & $\begin{array}{l}5 \cdot 95 \\
1 \cdot 0 \\
5 \cdot 2 \\
2 \cdot 0 \\
5 \cdot 1 \\
3 \cdot 0\end{array}$ & $\begin{array}{l}5 \cdot 2 \\
0 \cdot 9 \\
5 \cdot 0 \\
1 \cdot 3 \\
4 \cdot 9 \\
1 \cdot 3\end{array}$ & $\begin{array}{l}4 \cdot 5 \\
0 \\
4 \cdot 5 \\
2 \cdot 9 \\
4 \cdot 6 \\
0 \cdot 9\end{array}$ \\
\hline Exp. 3 & $\begin{array}{l}A Z U L \\
A C R U Z\end{array}$ & $\begin{array}{l}\mathrm{V} \\
\mathrm{I} \\
\mathrm{V} \\
\mathrm{I}\end{array}$ & $\begin{array}{l}6 \cdot 7 \\
0 \\
5 \cdot 8 \\
0\end{array}$ & $\begin{array}{l}6 \cdot 7 \\
0 \cdot 4 \\
5 \cdot 7 \\
1 \cdot 3\end{array}$ & $\begin{array}{l}6 \cdot 5 \\
0 \\
5 \cdot 5 \\
0 \cdot 7\end{array}$ & \\
\hline
\end{tabular}

列 10 plaque-forming units $/ \mathrm{ml}$.

I ISV production in interferon-tio VSV production in control minu

titre varied, being in some experiments on the second day and in others on the fourth. The absolute amounts of interferon varied from experiment to experiment, and this variation may be due to differing susceptibility of tongue tissue. However, within experiments on the same source of tongue tissue production of interferon by the virulent strains was less than that by the attenuated strains.

The sensitivity of $O V E N$ and $A T T$ VI strains to interferon was tested using interferon produced by infection of surviving tongue epithelial cultures with Semliki forest virus $(S E V)$. The amount of $O V E N$ virus produced was slightly higher in $S F V$-interferon-treated cultures than in controls, but in interferon-treated cultures there was a 3-5-fold reduction in $A T T V I$ virus produced, although the same preparation caused a 20-fold reduction in $V S V$ titre. In auto-interference experiments $A T T V I$ interferon brought about a 6 -fold reduction in titre of $A T T V I$ challenge virus, but had no effect on the virulent strain.

Preparations of $O V E N$ and $A T T V I$ interferons in $B H K 21$ cells had no effect against bovine enterovirus $M 6$. However, French neurotropic and $17 D$ interferons inhibited plaque formation by all strains, but the number of plaques was reduced to a greater extent in the case of $A T T X I I$ and $A C R U Z$ strains (Table 2). No experiments were made to determine a correlation between avirulence for hamsters and interferon sensitivity in $B H K 21$ cells.

Table 2. SEnsimivity of VIRULENT and ATtentated Strains to InterFERON PRODUCED IN BHK 21 CELLS

Interferon produced by: 'Tested against: Log reducti on in

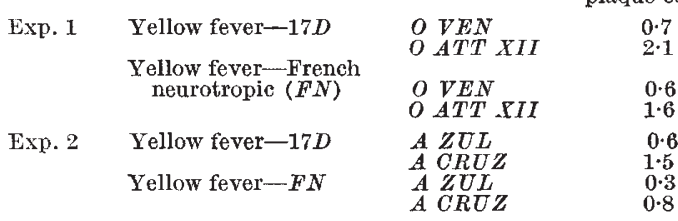

Owing to the use of fragments of surviving bovine tongue tissue discussion of the mechanism of interferon production is difficult. It generally occurred after virus production, but the amount of interferon present in the cells was not determined. More precise knowledge of the sequence of events might be obtained by the use of single cell suspensions infected with a known virus-cell ratio. However, despite this there appears to be a correlation between lack of virulence in cattle and reduced multiplication with increased interferon production and sensitivity in surviving cattle tongue epithelium. Since surviving tongue epithelial cultures are most closely related to tissues in the animal, it is reasonable to suppose that inoculation of the tongue with an avirulent strain leads to production of interferon, thus inhibiting lesion development. The sensitivity of the attenuated strain to its own interferon was less than that of $V S V$, but possibly interferon concentration in the tongue of the inoculated animal may be higher than in tissue cultures owing to the dilution factor of the medium. Other factors, however, are probably involved in lack of virulence ${ }^{6}$.
Since a desirable attenuated strain for use as a vaccine is considered to be one that contains virus that multiplies without production of lesions, an application of these findings would be the use of enhanced interferon production as a marker. Reversion to virulence could also be investigated by measuring interferon production after passage of attenuated strains in surviving tongue epithelial cultures.

Although the pattern of virus multiplication was comparatively constant in the experiments, yields of interferon varied. Variation in response of cattle to intradermal tongue inoculation of attenuated strains has been noted within and between breeds ${ }^{13,14}$. This may have been due to virulent virus in the attenuated strain, but it could have been variation in the ability to produce interferon. This might be tested by examining interferon production in tongue cultures from different breeds of cattle.

Departamento de Virologia,

Instituto Venezolano de

Investigaciones Cientificas, Caracas, Venezuela.

1 Dinter, Z., and Philipson, L., Proc. Soc. Exp. Biol. Med., 109, 893 (1962). ${ }^{3}$ Enders, J. F., Trans. Coll. Physicians Phila., 28, 68 (1960).

3 De Maeyer, E., and Enders, J. F., Proc. Soc. Exp. Biol. Med. (in the press; quoted by ref, 6$)$.

- Wagner, R. R., Proc. Cold Spring Harbor Symp. Quant. Biol. (in the press; quoted by ref. 6).

5 Ruis-Gromez, J., and Isaacs, A., Virology, 19, 1 (1963).

Ruis-Gomez, J., and Isaaes, A., Virology, 19, 8 (1963).

Palacios, C. A., Fuentes, R. A., Castañeda, J., and Maldonado, A., Bol. Inst. Inv. Vet., Maracay, 12, 3 (1960).

${ }^{8}$ Zahran, G. E. D., Amer. J. Vet. Res., 22, 527 (1961).

9 Frenkel, H. S., Bull. Off, int. Epiz., 28, 155 (1947).

${ }_{10}$ Macpherson, I. A., and Stoker, M. G. P., Virology, 16, 147 (1962).

${ }^{11}$ Mowat, G. N., and Chapman, W. G., Nature, 194, 253 (1962).

${ }^{12}$ Sellers, R. F., and Fitzpatrick, M., Brit. J. Exp. Pathol., 43, 674 (1962).

13 Brooksby, J. B., Thorp, A. C. P., Davie, J., Mowat, G. N., and O'Reilly, K. J., Res. Vet. Sci., 3, 315 (1962).

14 Mowat, G. N., and Prydie, J., Res. Vet. Sei., 3, 368 (1962).

\section{Nomenclature of Isolates of Virus from Trachoma and Inclusion Blennorrhœa}

THE system of nomenclature proposed for strains of trachoma/inclusion conjunctivitis (TRIC) agents $^{\mathbf{1}}$ provides the essential information with reasonable economy of symbols. Nevertheless, the fact that the full designations are rather cumbersome may militate against their general adoption. It should therefore be pointed out that when writing about a given strain the full designation need not be given after the first mention; thereafter it can be referred to by 'element (d)' only. 'Thus TRIC/2/SAU/HAR-2/OT' becomes $H A R-2$.

Lister Institute of Preventive Medicine,

L. H. Collier

Chelsea Bridge Road,

London, S.W.1.

${ }^{1}$ Gear, J. H. S., Gordon, F. B., Jones, B. R., and Bell, jun., S. D., Nature, 197, 26 (1963).

\section{MISCELLANEOUS}

\section{A New System for Thin-layer Chromatography}

IN a relatively short time paper chromatography has become an indispensable tool for separating and analysing the most varying kinds of chemical compounds. In the past few years a valuable modification of this method has been developed, namely, thin-layer chromatography.

Stahl, to whom much credit for the success of this method is due, has recently edited a comprehensive collection of the experiences gained so far ${ }^{1}$. Randerath ${ }^{2}$ deals extensively with the various modes of procedures used by different authors. Still more recently, Truter has written 